\title{
ПЕРВЫЕ РОССИЙСКИЕ НАУЧНЫЕ АРКТИЧЕСКИЕ ЭКСПЕДИЦИИ ВРЕМЕН М.В. ЛОМОНОСОВА
}

\section{Лобанов К.В., Чичеров М.В.}

Институт геологии рудных месторождений, петрографии, минералогии и геохимии РАН, Москва, lobanov@igem.ru,chicher@igem.ru

В XVI-XVII вв. зона промысловой и торговой деятельности стала более обширной. Поморские промысловики и мореходы доходили по заполярной территории Западной Сибири до устья Енисея, ходили на Новую Землю, на Шпицберген и прибрежные острова Баренцева и Карского морей.

Многих иностранных путешественников привлекала идея о том, что через северные моря можно достичь Китая. В XVI-XVII вв. состоялось несколько английских голландских и датских экспедиций на север. Однако, несмотря на все усилия, пройти восточнее Новой Земли этим экспедициям не удалось [1].

К началу интенсивного продвижения на восток в Арктической зоне, поморы создали суда в наибольшей степени приспособленные для плавания в северных морях известные под общим названием «коч». Характерной особенностью конструкции кочей была ложкообразная форма корпуса и усиленная двойная обшивка бортов, что позволяло им уверенно двигаться среди плавающих льдин и давало им способность выжиматься на поверхность ледяного покрова при сильном сжатии льдов.

Однако в XVIII в. Петр I запретил строительство кочей и потребовал впредь строить суда только по европейским проектам. Многие из этих европейских судов не были приспособлены для плаваний в северных морях и были слишком дороги для поморов. Этот указ привел к упадку кораблестроения у поморов. Ко времени проведения Великой Северной экспедиции опыт строительства кочей был практически утрачен.

\section{Великая Северная экспедищия 1733-1743 22.}

Великая Северная экспедиция 1733-1743 гг. - одна из крупнейших русских экспедиций, проект которой разрабатывался Сенатом совместно с Адмиралтейств-коллегией и Петербургской академией наук. Руководители - Витус Беринг и Алексей Чириков. В ней участвовало около 3000 человек, разделенных на несколько отрядов, выполнивших огромный комплекс исследований от устья

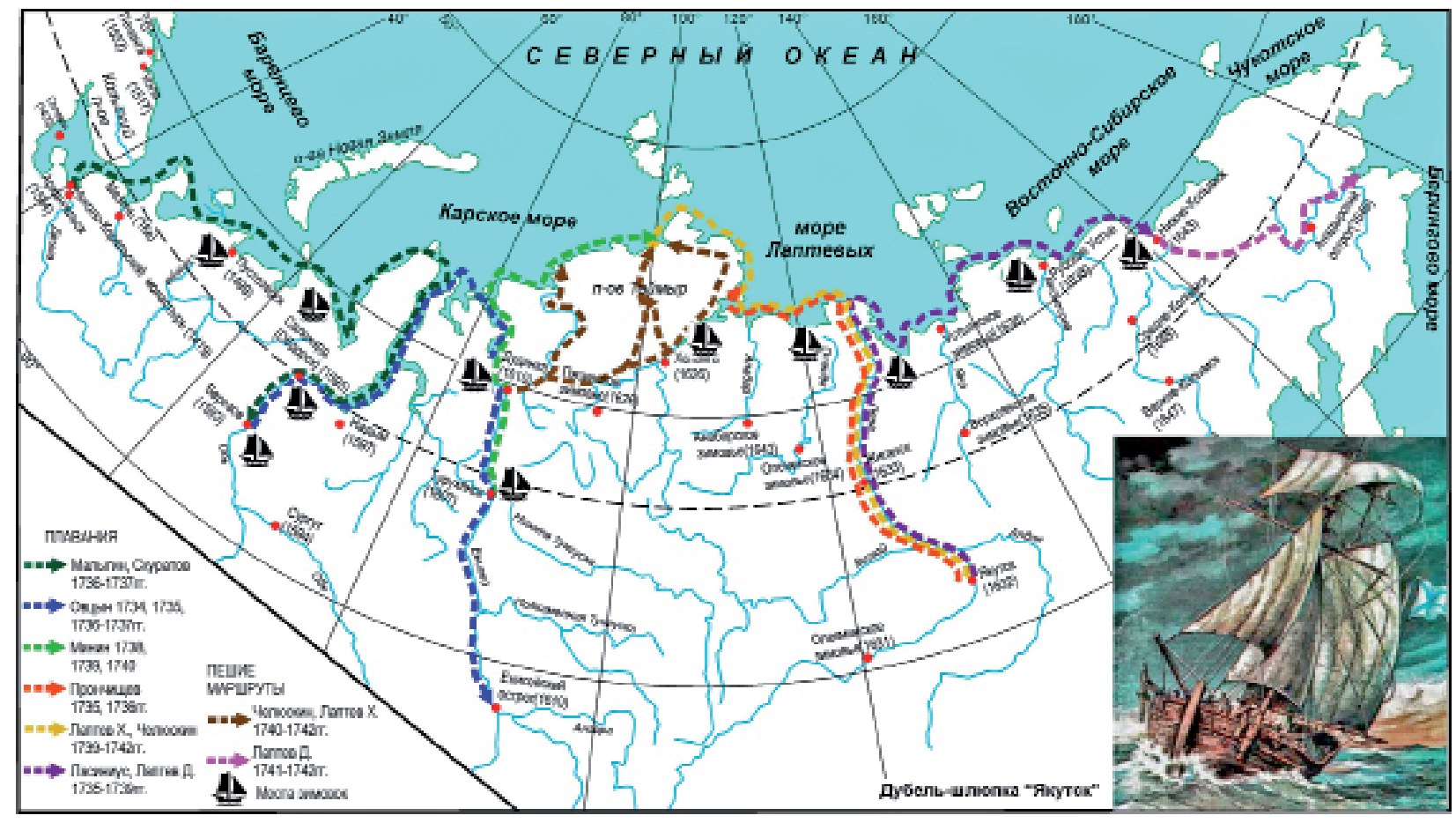

Рис. 1. Маршруты северных отрядов Великой северной экспедиции 1733-1743 гг. 
Печоры и острова Вайгач до Чукотки, Командорских островов и Камчатки. Стоимость экспедиции составила огромную сумму в 360659 рублей золотом [2].

Основной задачей экспедиции было поставлено исследование севера России от Печоры до Чукотки и составление его географического, геологического, ботанического, зоологического и этнографического описания. Кроме того, планировались морские походы к берегам Японии и Северной Америки. 28 декабря 1732 г. указ об организации экспедиции был представлен Сенатом на высочайшее утверждение.

Экспедиция состояла из девяти самостоятельных отрядов, экспедиции которых состоялись в 1733-1743 гг. Побережье Северного Ледовитого океана было разбито на пять участков, каждый из которых изучал отдельный отряд (рис. 1).

Самый западный участок побережья от Печоры до Оби должен был исследовать отряд под командованием Степана Муравьёва (позже его сменил Степан Малыгин), подчинявшийся непосредственно Адмиралтейств-коллегии. Все остальные отряды находились под общим руководством Витуса Беринга. Участок арктического побережья России от Оби до Енисея обследовал отряд Дмитрия Овцына и Дмитрия Стерлегова. Восточнее Енисея работал отряд Федора Минина. Участок побережья к западу от Лены был поручен отряду Василия Прончищева, Харитона Лаптева и Семена Челюскина. Участок побережья к востоку от Лены обследовал отряд Петра Лассниуса и Дмитрия Лаптева.

Основными судами северных отрядов Великой северной экспедиции, были так называемые дубель-шлюпки и боты, которые строились по чертежам, присланным из Петербурга.

Северные отряды Великой Северной экспедиции за десять лет изнурительного труда, ценою многих жизней положили на карту берега Северного Ледовитого океана от устья Печоры до мыса Большой Баранов (более 13 тыс. км). Они завершили открытие всего материкового побережья Карского моря и той, лежащей к востоку от Таймыра, акватории Ледовитого океана, которая с 1913 г. по справедливости называется морем Лаптевых, в честь Харитона Прокофьевича и Дмитрия Яковлевича.

К востоку от этого моря они положили на карту берега Восточно-Сибирского моря до устья Колымы и побережье за ней до Большого Баранова мыса. Отчетливо выявлены очертания полуостровов Таймыр (с самой северной точкой материка - мысом Челюскин) и Ямал, менее отчетливо - форма Гыданского и Тазовского п-овов. Описаны большие участки нижнего, а иногда и среднего течения всех крупных рек бассейна Ледовитого океана к востоку от Печоры до Колымы включительно.

Впервые сравнительно точно нанесены на карту части: Карского моря - Байдарацкая, Обская и Тазовская губы, Енисейский и Пясинский заливы; моря Лаптевых - Хатангский и Оленекский заливы, губа Буор-Хая и Янский залив. Собраны данные о климате, приливах и ледовом режиме обследованных морей, выявлены мели и скалы, представляющие опасность для судоходства, определены фарватеры.

\section{Экспедиция В.Я. Чичагова 1765-1766 г2.}

В 1755 г. М.В. Ломоносов представил правительству «Письмо о северном ходу в Ост-Индию Сибирским океаном», а в 1763 г. представил цесаревичу Павлу «Краткое описание разных путешествий по северным морям и показания возможного проходу Северным океаном в Восточную Азию». Обобщив опыт плаваний поморов и работы морских офицеров - участников Великой Северной экспедиции вдоль сибирского побережья, он выдвинул смелое предположение, что удаленное от берега пространство Ледовитого океана летом может быть свободным от тяжелых льдов (рис. 2).

14 мая 1764 г. Екатерина II издает указ об организации экспедиции, для поисков прохода через Северный океан на восток. Экспедиция была строжайше засекречена. Официально она называлась экспедицией для «Возобновления китовых и других звериных и рыбных промыслов на Шпицберген» [4].

Руководителем экспедиции был назначен В.Я. Чичагов. В команды кораблей отбирались опытные офицеры и матросы, а также поморы, ходившие на Шпицберген и Новую Землю. Всем участникам экспедиции было назначено двойное жалование, а все офицеры были повышены в звании. На экспедицию было выделено 20000 рублей. 


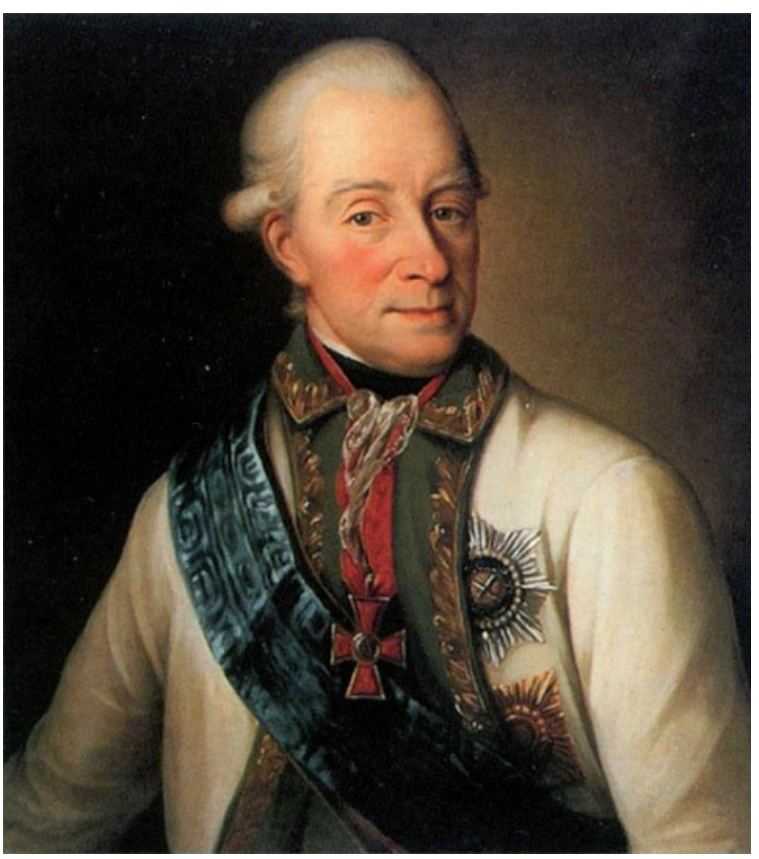

Чичагов В.Я.

Тщательно подбиралось снаряжение экспедиции. Для команды была пошита теплая меховая одежда. Помимо необходимых запасов продовольствия были приготовлены различные противоцинготные средства.

Ломоносов принимал самое деятельное участие во всех совещаниях по подготовке экспедиции, писал инструкцию, выбирал и заказывал инструменты и научные приборы, которые изготовили в мастерских Петербургской Академии наук, учил отправляющихся в экспедицию пользоваться ими. Всего экспедиция имела 31 навигационный инструмент.

Для экспедиции в Архангельске были специально построены три судна, которые получили названия в честь своих командиров: «Чичагов», «Бабаев», «Панов». Корпуса сделали особо прочными, форштевень и ахтерштевень обили железом. По совету Ломоносова наружную обшивку выполнили двухслойной, с расширенным ледовым поясом - как на кочах. Всего состав экспедиции насчитывал 178 человек, в том числе 29 кормщиков и промышленников из поморов.

В это же время (4 мая 1764 г.) был подписан указ Екатерины II об организации экспедиции П.К. Креницына - М.Д. Левашова (1764-1769) для описания неизвестных островов в Тихом океане. Экспедиция была секретной и называлась «Комиссией для описи лесов по рекам Каме и Белой». В случае удачного стечения обстоятельств экспедиция должна была встретиться с экспедицией Чичагова.

Летом 1764 г. в бухту Клокбай на западном берегу острова Западный Шпицбергена был послан вспомогательный отряд под командованием лейтенанта Михаила Степановича Немтинова, который привез на Шпицберген заготовленные заранее избы, баню, амбар и провизию для организации базы на случай зимовки экспедиции.
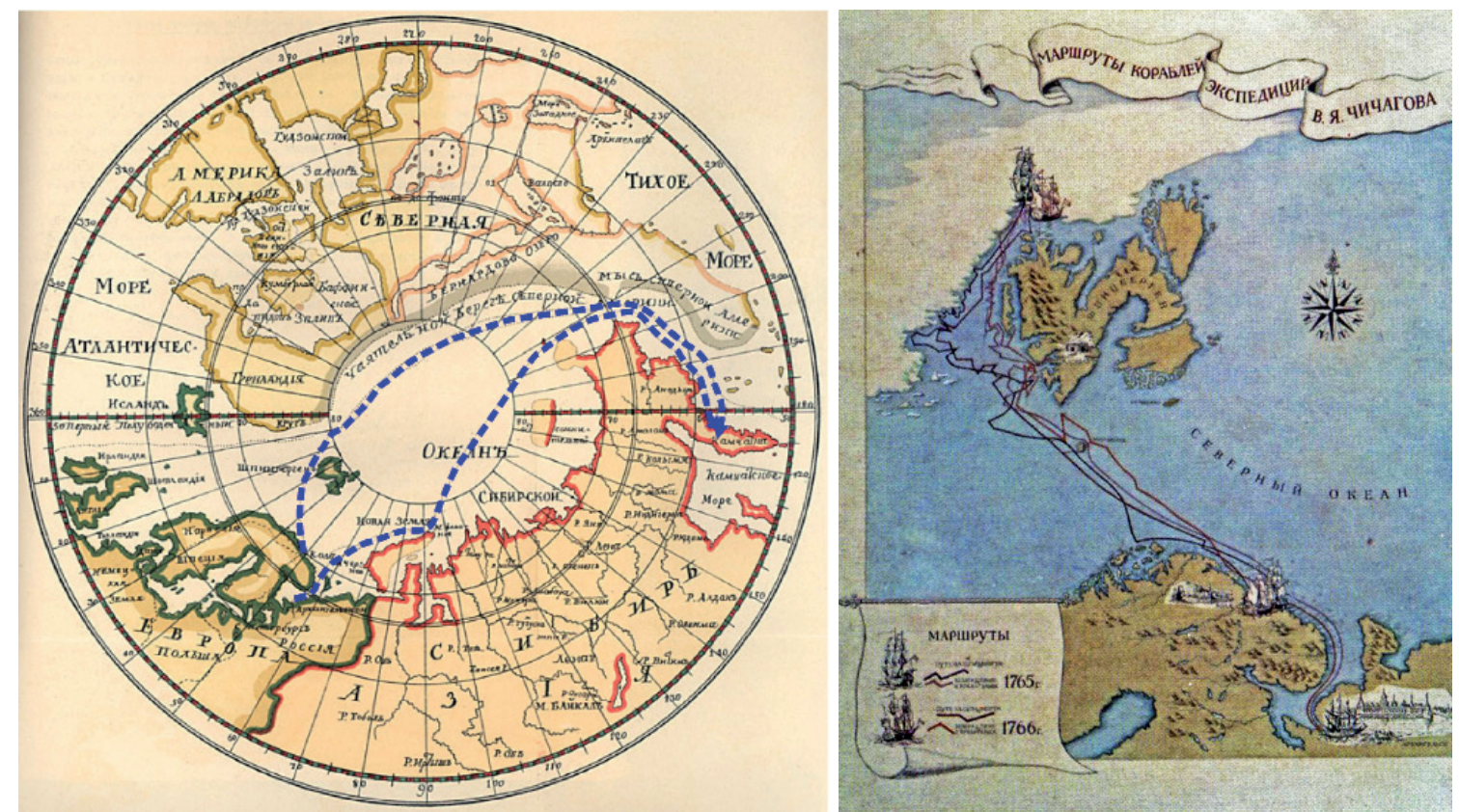

Рис. 2. Полярная карта, приложенная к рукописи «Краткое описание разных путешествий по северным морям и показание возможного проходу Сибирским океаном в Восточную Индию», выделены предполагаемые маршруты экспедиции [3]. Маршруты экспедиции Чичагова В.Я. 


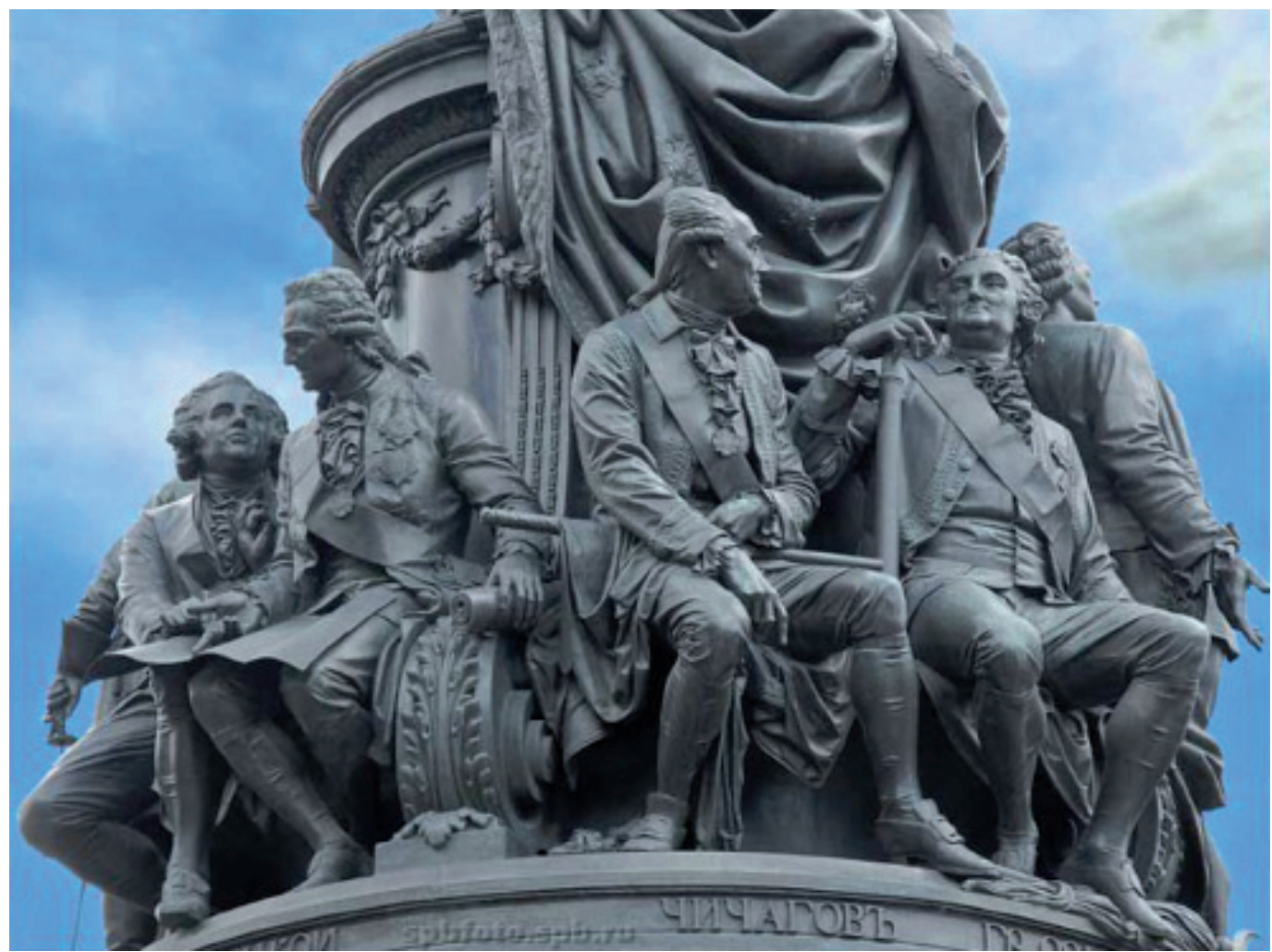

В.Я. Чичагов на памятнике Екатерине II.

1 сентября 1764 г. экспедиция, вышла из Архангельска в Колу и зимовала в Екатерининской гавани на Кольском полуострове. 9 мая 1765 г. корабли вышли в море, 16 июня достигли бухты Клокбай. 3 июля корабли вышли в море и двинулись на запад. 23 июля достигли $80^{\circ} 26^{\prime}$ северной широты, и вынужден были повернуть назад. 20 августа экспедиция вернулась в Архангельск, доложив, что проход на север невозможен. Адмиралтейство приказало повторить попытку на следующий год.

В 1766 г. В.Я. Чичагов совершил вторую попытку пройти в высокие широты, но смог достигнуть только 80³0’ северной широты, встретив далее непроходимые льды. 10 сентября корабли, забрав отряд Рындина со Шпицбергена, прибыли в Архангельск. Адмиралтейством было принято решение о прекращении поисков прохода в Тихий океан.

Несмотря на то, что экспедиция В.Я. Чичагова не выполнила поставленных перед ней задач, она внесла значительный вклад в развитие арктического мореплавания. Экспедиция достигла рекордной по тем временам широты к северу от Шпицбергена. Кроме того, это была первая полярная экспедиция, основанная на научном расчете. Ее участниками были выполнены геофизические, океанографические и метеорологические наблюдения по специальной программе, разработанной М.В. Ломоносовым, были проведены наблюдения над течениями и дрейфом льда в Гренландском море, взяты пробы грунта, во многих местах измерены глубины, описан животный и растительный мир Шпицбергена. Указом императрицы Екатерины II все участники экспедиции были щедро награждены.

\section{Литература}

1. Белов М.И. Арктическое мореплавание с древнейших времен до середины XIX в. // История открытия и освоения Северного морского пути. Т. 1. Морской транспорт. Москва. 1956. 596 с.

2. Бондарский М.С. Великий северный морской путь: историко-географический очерк открытия Северовосточного прохода / М.-Л. Гос. изд-во. 1926. 251 с.

3. Ломоносов М.В. Краткое описание разных путешествий по северным морям и показание возможного проходу Сибирским океаном в Восточную Индию // Ломоносов М.В. Полн. собр. соч. М.-Л. Изд-во АН CСCР. 1952. Т. $6.694 \mathrm{c}$.

4. Соколов А.П. Проект Ломоносова и экспедиция Чичагова. М: Паулсен. 2015. 136 с. 